\title{
Pengembangan Komoditas Unggulan Perkebunan Berbasis Modal Sosial dan Peluang Investasi di Aceh
}

\author{
Ira Manyamsari $1^{*}$, Romano $^{2}$, Mujiburahmad $^{3 *}$, Ramayana $^{4}$ \\ 1,2,3,4 Prodi Agribisnis Fakultas Pertanian Universitas Syiah Kuala, Indonesia. \\ *Corresponding author's e-mail: mujiburrahmad@unsyiah.ac.id
}

\begin{abstract}
ABSTRAK
Pembangunan perkebunan di Aceh difokuskan pada pengembangan komoditas unggulan daerah. Pembangunan untuk mendukung mata pencaharian masyarakat dan penumbuhan agroindutry. Penelitian ini dilakukan di Aceh dengan metode survei. Analisis model hirarki, LQ, kriteria investasi, spesialisasi dan diversifikasi. Studi menemukan bahwa pengembangan perkebunan di Aceh belum sesuai dengan potensi sentra produksi di setiap kabupaten. Terpilih sebagai primecommodity di Aceh kelapa sawit, kopi, kakao, karet, kelapa, dan pinang telah menjadi andalan masyarakat sebagai sumber mata pencaharian dari sektor perkebunan. Strategi besar dari pengembangan komoditas di Aceh adalah strategi diversifikasi atas dasar kombinasi potensial, jenis komoditas dan infrastruktur untuk mendukung agribisnis. Setiap kabupaten serta mengembangkan beberapa komoditas untuk mengantisipasi fluktuasi harga komoditas
\end{abstract}

Kata Kunci:

LQ; perkebunan; revitalisasi; strategi

\begin{abstract}
Aceh development plantation focused in regional potential commodity development. The development to supported livelihood society dan agroindustry growth. This research did in Aceh with survey method and the analysis used hierarki model, $L Q$, investment criteria, specialization and diversification. Result showed that Aceh plantation development wasn't suitable with potential production center in each district. The prime commodity in Aceh such as palm oil, coffee, cocoa, rubber, coconut and areca have been people mainstay as a source of livelihood in plantation sector. Main strategy from commodity development in Aceh wa a diversification strategy based on potential combination, commodity type and infrastructure to support agribusiness. Every district develop some commodity to anticipate price fluctuation.
\end{abstract}

Keywords:

LQ; plantation; revitalization; strategy

How to Cite: Manyamsari, I., Romano., Mujiburahmad., Ramayana. (2019). Pengembangan Komoditas Unggulan Perkebunan Berbasis Modal Sosial dan Peluang Investasi di Aceh. Jurnal Penelitian Agrisamudra. 6(1): xx-xx 


\section{Pendahuluan}

Fokus pembangunan subsektor perkebunan dengan di Aceh adalah meningkatkan penghasilan masyarakat dan penumbuhan agroindustri bernasis produk perkebunan. Perkebunan di Aceh memiliki prospek yang baik di masa depan, sebagai sumber pertumbuhan ekonomi dan penciptaan lapangan kerja. Kondisi yang ada terkait dengan peningkatan produksi perkebunan dapat dilakukan dengan menentukan komoditas. Secara umum, ada 11 komoditas yang telah dikembangkan oleh masyarakat di Kabupaten Aceh. Di antara sebelas komoditas perkebunan yang telah berevolusi di daerah ini, beberapa dari mereka dapat dikategorikan sebagai bagian dari wilayah komoditas dan komoditas nasional. Komoditas nasional terdiri dari kelapa sawit, kakao, tembakau, karet dan kopi. Daerah komoditas seperti: kelapa, kakao, pinang, pala dan merica. Merica, meskipun areal, produksi dan nilai produksi yang relatif kecil, Aceh telah membuat karet dan kelapa sawit sebagai daerah produksi utama.

Fenomena lain menunjukkan bahwa kondisi di daerah sentra produksi komoditas perkebunan kontras dengan luas tanaman kondisi yang ada, produksi dan produktivitasnya. Sebagian besar tanaman kelapa tumbuh di Kabupaten Aceh Timur, Aceh Tengah, Aceh Barat, dan Aceh Selatan; yang lebih cocok untuk pengembangan tanaman pangan. Sementara di Kabupaten Nagan Raya, Abdya, Aceh Barat dan Aceh Jaya harus sesuai untuk pengem-bangan tanaman biji-bijian dan perkebunan.

Berdasarkan phenoma ini, dapat disimpulkan bahwa pengembangan komoditas terbaik di Kabupaten Aceh belum sepenuhnya dikaitkan dengan potensi yang ada di wilayah ini sehingga hasil yang diinginkan tidak sesuai dengan kenyataan di lapangan, terlepas dari produktivitas yang terlihat meningkat. Namun, peningkatan produktivitas jelas, dan hal ini tentunya banyak faktor yang mempengaruhinya, terutama kesesuaian lahan di wilayah masing-masing di Aceh.

Potensi daerah untuk pengembangan subsektor komoditas adalah wilayah besar untuk perkebunan. Hal ini terbukti dalam perencanaan pembangunan di sektor pertanian didasarkan pada Tata Ruang (area untuk pengembangan komoditas perkebunan). Namun, masalah yang dihadapi, khususnya dalam pengelolaan sumber daya alam yang berorientasi pada lingkungan masih memiliki kendala, di mana, jika tidak diakui oleh para pihak, masalah ini akan menghasilkan pemborosan sumber daya yang semakin langka dalam mengembangkan potensi di wilayah ini. Penelitian ini bertujuan untuk menilai kesesuaian pengembangan potensi berbasis komoditas daerah; kelayakan pengembangan komoditas perkebunan yang terbaik sub-sektor di Aceh dan mengkaji strategi pengembangan komoditas untuk sektor perkebunan daerah di Aceh.

\section{Metode Penelitian}

Penelitian ini dilakukan dengan sejumlah metode yang dirangkum dalam pendekatan proses hirarki. Metode pertama adalah metode eksplorasi di mana data sekunder diperoleh dari kondisi umum dari komoditas perkebunan yang ada dalam lima tahun 
(2006 hingga 2010) lalu. Kemudian, peta tanah potensial dan kondisi agroklimat di Aceh dikumpulkan. Atas dasar ini komoditas andalan perkebunan Aceh dari masing-masing kabupaten akan ditentukan. Metode kedua adalah metode survei. Hal itu dilakukan dengan mewawancarai petani kelapa sawit, karet, kopi, kelapa, kemiri, Kakao dan lada. Teknik sampling yang digunakan adalah tiga tahap grup random sampling (Cluster multi Tahap Random Sampling). Populasi adalah petani dari komoditas perkebunan Aceh. Tahap pertama adalah untuk memilih 10 kabupaten sebagai pusat produksi komoditas perkebunan Aceh. Tahap kedua adalah pemilihan kecamatan sentra produksi di setiap kabupaten terpilih. Tahap ketiga adalah pemilihan petani sebagai sampel, yang diambil secara acak sesuai dengan jenis perkebunan komoditas yang dibudidayakan oleh $20 \%$ dari petani yang mengelola perkebunan. Jumlah penduduk akan ditentukan oleh masing-masing kabupaten dipilih komoditas. Jumlah populasi adalah jumlah rumah tangga yang memiliki lima komoditas yang akan dipilih. Sesuai dengan persyaratan sesuai dengan jenis dan sumber data dapat dijelaskan oleh kebutuhan menjawab masalah penelitian. Untuk menjawab tujuan penelitian data sekunder (1) diperlukan yang dikumpulkan dari laporan Dinas Perkebunan Aceh, BAPPEDA, dan statistik Dewan Aceh. Untuk menjawab tujuan penelitian (2) perlu data primer yang dibutuhkan untuk dikumpulkan dari petani 20 persen dipilih berdasarkan komoditas perkebunan. Selanjutnya, untuk menjawab tujuan penelitian (3) diperlukan sekunder, hasil primer, dan data verifikasi Focussed Group Discusión (FGD) dengan kepala Pertanian Produksi, Penyuluhan Tanaman dan petani yang mencari perkebunan komoditas di Aceh.

Model analisis yang digunakan adalah sesuai lima parameter di atas diurutkan komoditas prioritas dalam kabupaten Aceh. Koreksi silang kemudian dilakukan untuk menemukan produksi komoditas sub-pusat. Tahap kedua adalah bahwa, alat analisis yang digunakan adalah Location Quotient (LQ) dihitung dengan rumus berikut (Warpani, 1984):

$L Q=\frac{S_{i} / N_{i}}{S / N}$

Dimana:

$\mathrm{LQ}=$ koefisien perkebunan commodi-ikatan lokasi

$\mathrm{Si}=$ Volume komoditas i di daerah / kabupaten

$\mathrm{S} \quad=$ Volume komoditas perkebunan daerah / kabupaten

$\mathrm{Ni} \quad=$ Volume komoditas i di tingkat dis-trict

$\mathrm{N} \quad=$ Volume komoditas perkebunan kabupaten

Nomor LQ menunjukkan hal berikut:

a. LQ> 1, menunjukkan komoditas ini termasuk basis komoditas.

b. LQ $<1$, menunjukkan komoditas ini termasuk dasar non-komoditas.

c. $L Q=1$, menunjukkan komoditas hanya dapat memenuhi wilayahnya sendiri. 
a. Koefisien lokalisasi (a)

Digunakan untuk menentukan penyebaran kegiatan komoditas di suatu daerah, sehingga kita akan mengetahui tingkat aglomerasi dengan menjumlahkan nilai dari daerah yang nilai a positif.

$$
\alpha=\left\{\left(\frac{S i}{N i}\right)-\left(\frac{S}{N}\right)\right\}
$$

\section{Dimana:}

$a=$ Koefisien Lokalisasi

$\mathrm{Si}=$ Jumlah (pendapatan, produksi) komoditas i pada tingkat regional

$\mathrm{S}=$ Jumlah (pendapatan, produksi) commodi-hubungan tingkat regional

$\mathrm{Ni}=$ Jumlah (pendapatan, produksi) komoditas i di tingkat kabupaten

$\mathrm{N}=$ Jumlah total kabupaten (pendapatan, produksi) komoditas $\mathrm{N}$

Nilai a memberikan indikasi berikut:

a. $\alpha=1$, menunjukkan lokalisasi kegiatan komoditas berpusat

b. $a<1$, menunjukkan lokalisasi kegiatan penyebaran komoditas.

b. Koefisien Spesialisasi $(\beta)$

Digunakan untuk menentukan spesialisasi daerah dalam kegiatan tertentu, sehingga kita dapat mengetahui keandalan komparatif dengan cara menjumlahkan nilai dari wilayah yang positif.

$$
\beta=\left\{\left(\frac{S i}{S i}\right)-\left(\frac{N i}{N}\right)\right\}
$$

\section{Dimana:}

$\beta \quad=$ koefisien Spesialisasi

Si $\quad=$ Jumlah (pendapatan, produksi) com-modity i di tingkat regional

$\mathrm{S} \quad=$ Jumlah (pendapatan, produksi) commodi-hubungan tingkat regional

$\mathrm{Ni} \quad=$ Jumlah (pendapatan, produksi) komoditas i di tingkat kabupaten

$\mathrm{N} \quad=$ Jumlah total kabupaten (pendapatan, produksi) komoditas $\mathrm{N}$

Angka $\beta$ menunjukkan berikut:

a. $\quad \beta=1$, yang menunjukkan daerah yang mengkhususkan diri dalam kegiatan komoditas.

b. $\beta<1$, menunjukkan tidak ada aktivitas khusus $\mathrm{n}$ komoditas di suatu wilayah

\section{Hasil dan Pembahasan}

\subsection{Potensi Daerah dan Pengembangan Perkebunan Komoditas Andalan}

Pemerintah Aceh masih ambisius untuk mengembangkan kelapa sawit dan kakao, tetapi dengan kondisi yang ada hanya 5 kandidat pada komoditas perkebunan masih 
memiliki potensi besar pembangunan, khususnya kelapa sawit, karet, merica dan pinang. Dalam hal produksi, urutan komoditas untuk produksi tanaman ditunjukkan pada grafik di bawah. Untuk produksi terbesar minyak sawit komoditas, karet, kakao, dan coffea kontribusi yang signifikan terhadap pendapatan petani. Kelapa sawit merupakan komoditas yang memiliki kontribusi terbesar terhadap produksi minyak dan perekonomian daerah, kemudian diikuti oleh karet, kopi, pala dan cocoas. Dengan kata lain, jika Anda mempertimbangkan aspek komoditas, produksi perkebunan kelapa menjadi kontributor utama produksi di Aceh. Kelapa sawit, kopi karet dan kakao yang paling komoditas permintaan seperti yang ditunjukkan oleh tren nilai produksi tertinggi. Selain itu juga menunjukkan nilai keberlanjutan dalam mendapatkan komoditas. Dalam hal kepastian pasar, lada dan kakao komoditas menunjukkan cukup tinggi untuk nilai indikator pasar. Selain itu, indikator ini juga menyediakan kemampuan informasi saing komoditas ini di pasar di distrik, untuk distrik pasar provinsi. Pada kriteria pekerjaan, kelapa merupakan komoditas yang memiliki tingkat kerja tertinggi. Pada indikator konsumsi yang didefinisikan sebagai kemampuan untuk meningkatkan pendapatan dan untuk memenuhi kebutuhan dalam negeri, ada dua jenis komoditas yang memiliki nilai tertinggi indikator, mereka Kelapa dan kopi.

Dalam pengambilan keputusan penetapan komoditas andalan, arah kebijakan harus dilakukan secara komprehensif dan terpadu atau sebagian. Artinya, penentuan komoditas andalan tidak hanya harus mempertimbangkan peningkatan produksi, atau peningkatan daya saing komoditas atau menangani kebutuhan konsumsi dalam negeri, tetapi juga seluruh aspek tujuan pembangunan seperti meningkatkan produksi, meningkatkan pendapatan petani, meningkatkan ketersediaan untuk konsumsi, menyerap tenaga kerja, meningkatkan ekspor atau komoditas daya saing dan meningkatkan peluang bisnis (trend) atau pekerjaan juga harus menjadi pertimbangan keputusan. Untuk itu, maka berbagai kriteria yang diperlukan dalam menentukan komoditas andalan, di mana komoditas yang akan dikembangkan untuk menjawab seluruh tujuan dari pembangunan komprehensif dan terpadu. Dalam rangka komoditas menentukan bisa lebih tepat, perlu untuk menganalisis pendapat para pemangku kepentingan yang dianggap cukup untuk mengetahui situasi dan kondisi Kabupaten Aceh, persyaratan untuk mendirikan komoditas yang diinginkan dan persepsi mereka tentang bagaimana komoditas harus dikembangkan di Aceh, serta setiap komoditas kabupaten dikembangkan. Berdasarkan metode AHP, persepsi pemangku kepentingan dianalisis untuk menghasilkan andalan prioritas komoditas vektor dan pusat-pusat pembangunan daerah.

Pendapat para pemangku kepentingan (penyuluh perkebunan, petani dan kepala produksi Perkebunan, Kehutanan dan Perkebunan Aceh) dalam penentuan komoditas andalan Aceh Besar didasarkan pada: (A) luas panen, (B) produksi, (C) produktivitas , (D) nilai produksi, $(\mathrm{E})$ sumber mata pencaharian, $(\mathrm{F})$ volume transaksi / pasar, dan $(\mathrm{G})$ konsumsi. Urutan komoditas prioritas didasarkan pada delapan kriteria di atas. Di mana kelapa sawit masih berdiri sebagai urutan pertama, kemudian diikuti oleh Karet, 
Kopi , lada, pinang, kakao, kopi, dan kelapa sawit; seperti yang ditunjukkan pada Tabel 1.

Tabel 1. Urutan Komoditas berdasarkan AHP di Aceh pada tahun 2011.

\begin{tabular}{lccccccc}
\hline \multirow{2}{*}{ Komoditi } & \multicolumn{7}{c}{ Rank Based On Criteria } \\
\cline { 2 - 8 } & A & B & C & D & E & F & G \\
\hline Kelapa Sawit & 1 & 1 & 1 & 1 & 1 & 1 & 1 \\
Kopi & 5 & 7 & 7 & 7 & 7 & 7 & 7 \\
Karet & 2 & 2 & 6 & 3 & 2 & 2 & 2 \\
Kakao & 3 & 3 & 2 & 4 & 3 & 4 & 5 \\
Pala & 7 & 6 & 6 & 2 & 6 & 6 & 5 \\
Nilam & 4 & 4 & 3 & 7 & 5 & 3 & 4 \\
Lada & 5 & 5 & 5 & 6 & 4 & 5 & 3 \\
\hline
\end{tabular}

Dasar untuk menentukan komoditas prioritas bervariasi menurut jenis tanaman dan daerah. Berdasarkan jenis, kelapa sawit sebagai peringkat pertama ditentukan oleh: tanah yang luasnya cocok dan sangat cocok di daerah ini; produksi, serta nilai-nilai produksi masing-masing komoditi. Selanjutnya, karet, sebagai komoditas kedua lini, ditentukan dari titik areal, luas panen, dan sumber volume mata pencaharian. Namun, berdasarkan nilai pasar dari transaksi, karet berdiri pada komoditas baris ketiga setelah kopi. Ini berarti bahwa sebagian besar kelapa yang dihasilkan diproses dan dikonsumsi di Kabupaten Aceh Besar.

Tabel 2. Keandalan Urutan Komoditas Perkebunan dan Pilihan Komprehensif Masyarakat.

\begin{tabular}{cccccc}
\hline \multirow{2}{*}{$\begin{array}{c}\text { Reability } \\
\text { Criteria }\end{array}$} & \multicolumn{5}{c}{ Smallholder Plantation Commodities } \\
\cline { 2 - 6 } & $\begin{array}{c}\text { Kelapa } \\
\text { Sawit }\end{array}$ & Karet & Kelapa & Kakao & Kopi \\
\hline A & 26 & 24 & 18 & 11 & 18 \\
B & 21 & 16 & 11 & 12 & 16 \\
C & 21 & 18 & 15 & 10 & 11 \\
D & 35 & 24 & 19 & 18 & 29 \\
E & 16 & 12 & 20 & 14 & 4 \\
F & 12 & 7 & 17 & 18 & 14 \\
G & 10 & 4 & 12 & 2 & 6 \\
\hline Total & 141 & 105 & 112 & 85 & 98 \\
\hline RS & 1 & 3 & 2 & 5 & 4 \\
\hline
\end{tabular}

Kemudian nilai transaksi terbesar keempat adalah cocoas adalah komoditas. Ini berarti bahwa cocoas diproduksi di daerah ini sebagian besar diperdagangkan di luar daerah. Hal ini karena unit untuk memproses tanaman ini tidak tersedia belum di Aceh.

\subsection{Kriteria Keandalan Komprehensif}

Kriteria reliabilitas yang komprehensif yang digunakan dalam penelitian ini seperti yang direkomendasikan oleh Warpani (1984), berdasarkan: (A) Pasar Kriteria dan 
Pemasaran, (B) Kriteria Teknologi Agribisnis, (C) Kriteria Lingkungan-mental, (D) Kriteria Perbandingan Relia-bility , (E) Kriteria Keandalan kompetitif, (F) Pendapatan dan Kriteria Kesejahteraan, (G) kriteria keunikan dan regional.

Atas dasar kriteria keandalan kompetitif dengan nilai parameter dan manfaat ekonomi, nilai tambah dan tinggi marjin, kualitas, dapat bersaing dengan daerah lain; juga menjadi urutan pertama kelapa sawit dan karet ke urutan terakhir. Atas dasar kriteria pendapatan dan kesejahteraan meter dengan kemampuan untuk meningkatkan pendapatan, sumber pendapatan petani atau agribisnis, memperluas lapangan kerja, dampak ekonomi yang tinggi pada masyarakat dan daerah; kemudian atasnya kelapa sawit dan Kopi peringkat ketujuh. Demikian pula, kriteria dasar keunikan dan daerah dengan parameter produk tertentu hanya Aceh, ciri khas daerah, memiliki karakteristik yang unik; kemudian lada ke urutan pertama. Selain analisis berdasarkan kriteria ini, penentuan potensi komoditi di kawasan itu juga dilakukan melalui analisis tanah dan agroklimat kesesuaian. Analisis dilakukan dengan meninjau tipologi ekologi agro di Kabupaten Aceh Besar mulai dari karakteristik lahan biofisik (sifat-sifat tanah dan iklim) sebagai parameter utama yang membedakan antara zona ekologi agro. Hasil analisis tersebut yang menggambarkan batas-batas zonasi agroekologi yang memiliki kesamaan atau kemiripan karakteristik biofisik dan jenis penggunaan lahan. Dasar tanah dan agroklimat kesesuaian peta menunjukkan bahwa sebagian besar wilayah Aceh tergolong cocok untuk pengembangan tujuh komoditas dengan potensi pengembangan perkebunan.

Tabel 3. Potensi Pengembangan Perkebunan Tanaman Rakyat diandalkan di Aceh.

\begin{tabular}{lrrr}
\hline $\begin{array}{c}\text { Prime } \\
\text { Commodity }\end{array}$ & $\begin{array}{c}\text { Potential } \\
\text { Development (Ha) }\end{array}$ & $\begin{array}{c}\text { Area Potential } \\
\text { (Ha) }\end{array}$ & $\begin{array}{c}\text { Relative } \\
\text { Potency (\%) }\end{array}$ \\
\hline Kelapa & 15.960 & 30.253 & 211,66 \\
Kelapa Sawit & 1.160 & 2.294 & 202,29 \\
Karet & 2.350 & 5.679 & 170,59 \\
Kakao & 2.950 & 5.868 & 201,10 \\
Areca & 1.500 & 2.966 & 202,32 \\
Kopi & 1.400 & 2.773 & 201,97 \\
Lada & 550 & 1.068 & 206,18 \\
\hline
\end{tabular}

Berdasarkan penanaman ekstensif karet dan kakao ke urutan terakhir kriteria keandalan komoditas perkebunan di daerah ini. Namun, berdasarkan potensi pengembangan relatif, ternyata menjadi urutan komoditas perkebunan kakao pertama yang bisa dibudidayakan di masa depan. Ini berarti bahwa pengembangan komoditas perkebunan belum mengacu pada potensi kondisi wilayah dan agroklimat serta nilai ekonomi.

Langkah terakhir untuk menentukan apakah sesuai atau tidak, adalah untuk membandingkan nilai LQ dengan hasil analisis potensi daerah. Hasil analisis menunjukkan bahwa komoditas urutan subsektor tidak setara untuk dikembangkan 
berdasarkan kedua analisis. Berdasarkan potensi relatif Aceh Besar agar Kabupaten komoditas pertama adalah kakao, yang kedua adalah Kakao. Namun, berdasarkan jumlah kabupaten dengan basis komoditas (LQ> 1) maka kelapa sebagai tanaman pertama dan kakao adalah urutan komoditas akhir. Meskipun analisis ini tidak konsisten dalam rangka sendiri, tetapi komoditas perkebunan ketujuh diterima sebagai komoditas Aceh.

Tabel 4. Komoditas urut Perbandingan andalan Berdasarkan relatif Potensi dan Jumlah Kecamatan sebagai Komoditas Base (LQ 1>).

\begin{tabular}{lrrrr}
\hline $\begin{array}{c}\text { Komoditi } \\
\text { Andalan }\end{array}$ & $\begin{array}{c}\text { Potensi } \\
\text { Relatif (\%) }\end{array}$ & Rank & $\begin{array}{c}\text { Kabupaten } \\
\text { LQ>1 }\end{array}$ & Rank \\
\hline Kelapa Sawit & 211,6 & 1 & 11 & 1 \\
Karet & 206,1 & 2 & 5 & 4 \\
Kakao & 170,5 & 5 & 7 & 3 \\
Kopi & 202,3 & 3 & 9 & 2 \\
Kelapa & 201,1 & 4 & 7 & 3 \\
\hline
\end{tabular}

Analisis LQ dilakukan untuk menentukan apakah subsektor komoditas yang telah dikembangkan telah dirancang sesuai dengan potensi daerah yang ada di setiap kabupaten. Hasil LQ untuk petani kecil sub-sentra produksi ditunjukkan pada Lampiran 16. Pada lampiran ini, dapat dilihat bahwa berdasarkan produksi, semua komoditas perkebunan telah dikembangkan sesuai dengan potensi daerah. Ini berarti bahwa hipotesis kerja diterima. Nilai LQ menunjukkan bahwa untuk semua komoditas di atas LQ> 1, menunjukkan komoditas ini termasuk komoditas yang berbasis di masing-masing kecamatan. Hanya di dua kabupaten yang memiliki beberapa komoditas ketiga dan keempat di mana $\mathrm{LQ}<1$, ini menunjukkan komoditas ini termasuk ke dalam dasar non-komoditas; Namun, hal itu telah dikembangkan di daerah ini di distrik seperti kelapa Lhoong, Lhoknga dan Seulimum.

Hasil analisis ini menunjukkan bahwa pengembangan basis komoditas dan tidak atas dasar subsektor komoditas di Aceh tidak benar-benar didasarkan pada kemampuan tanah untuk menghasilkan produksi. Seperti yang telah dijelaskan di peta kesesuaian lahan, tidak ada semua komoditas sedang dikembangkan berpotensi di kabupaten masing-masing. Untuk kabupaten Mesjid Raya, yang sebagian besar wilayah yang cocok untuk pengembangan cocoas, namun produksi kakao di daerah ini sangat kecil. Dengan demikian, analisis LQ menyatakan Kakao bukan basis komoditas, dengan $L Q=0,10$. Hal lain yang penting untuk dicermati adalah bahwa budidaya basis komoditas di daerah yang tidak intensif Aceh. Jadi komoditas dasar belum memiliki kriteria keandalan dalam hal sumber mata pencaharian.

Dengan demikian, hipotesis (1) dapat diterima bahwa perkembangan komoditas petani kecil di Aceh tidak konsisten dengan potensi masing-masing sentra produksi subregion. Beberapa faktor yang menyebabkan inkonsistensi ini, antara lain: (a) pengembangan petani tidak sesuai dengan rencana induk perkebunan Aceh yang telah diterbitkan sejak tahun 2009, (b) sebagian besar perkebunan rakyat dalam organisasi 
Aceh masih mengandalkan pada pemahaman komoditas masih rendah, (c) belum mengalokasikan anggaran untuk pembangunan perkebunan yang optimal; (D) peran lembaga tinggi aktif pendidikan rendah untuk menguji kesesuaian potensi daerah dengan daerah komoditas.

\subsection{Potensi Hubungan dengan Daerah Kabupaten Spesialisasi atau Diversifikasi Pilihan}

Kabupaten, sebagai unit terkecil daerah memiliki potensi yang berbeda dalam mengembangkan kedua spesialisasi komoditas dan diversifi-kation. Sesuai dengan pendapatan David Hendri (2005) bahwa untuk mengetahui perkembangan daerah yang dapat dioptimalkan dengan spesialisasi atau diversifikasi komoditas dengan menggunakan beberapa alat analisis yang meliputi: (a) koefisien lokalisasi (a), (b) koefisien spesialisasi $(\beta)$.

(a) koefisien Lokalisasi ( $a$ )

Analisis kegiatan penyebaran untuk mengembangkan komoditas di Aceh menggambarkan tingkat aglomerasi. Produksi setiap perkebunan tanaman komoditas tersebar di berbagai kabupaten sesuai dengan sentra produksi mereka. Namun ini telah berpusat pada sentra produksi masing-masing komoditas. Hal ini tercermin dalam koefisien komoditas lokalisasi. Hanya Kakao lokalisasi memiliki koefisien (a)>1. Total produksi kelapa di 22 kabupaten bervariasi. Demikian pula, di lima kabupaten, distribusi produksi tersebar merata sehingga dapat disimpulkan bahwa lokalisasi kebun kelapa tidak terpusat. Hal ini mirip dengan cocoas, kopi, karet, pinang dan merica. Dari pengujian hipotesis ini dapat disimpulkan bahwa pengembangan komoditas petani di Aceh tidak bertemu sesuai dengan perkembangan poligon.

(b) Spesialisasi koefisien $(\beta)$

Analisis Spesialisasi koefisien $(\beta)$ digunakan untuk menentukan spesifikasi komoditas yang dikembangkan di sub-wilayah tertentu, sehingga untuk mengetahui keandalan komparatif. Komponen parameter yang tepat dalam analisis adalah pendapatan yang berasal dari petani kecil pertanian terutama komoditas tertentu.

Tabel 6. Parameter Analisis Spesialisasi dan Diversifikasi Komoditas Orang Estate di Aceh.

\begin{tabular}{lccc}
\hline \multicolumn{1}{c}{$\begin{array}{c}\text { Komoditi } \\
\text { Comodity }\end{array}$} & $\begin{array}{c}\text { Jumlah } \\
\text { Kabupaten LQ>1 }\end{array}$ & $\begin{array}{c}\text { Koefisien } \\
(\mathbf{\alpha})\end{array}$ & $\begin{array}{c}\text { Koefisien } \\
(\boldsymbol{\beta})\end{array}$ \\
\hline Kelapa (coconut) & 11 & $-1,16$ & $-1,97$ \\
Karet (Havea) & 5 & $-1,10$ & 0,93 \\
Kakao (cocoa) & 7 & 0,41 & $-0,52$ \\
Kelapa Sawit (Palm Oil) & 9 & 0,46 & 0,47 \\
Kopi (coffea) & 7 & $-0,01$ & 0,31 \\
\hline
\end{tabular}

Hasil analisis untuk perkebunan tujuh komoditas di Kabupaten Aceh Besar menunjukkan nilai $\beta<1$. Mengacu pada dasar distribusi kabupaten dengan nilai LQ> 1 
untuk semua komoditas, itu menunjukkan bahwa empat atau lebih kabupaten memiliki hampir komoditi yang sama. Ini berarti bahwa tidak ada satu daerah di Kabupaten Aceh Besar yang mengkhususkan tanaman komoditas. Semua kabupaten itu diversifikasi komoditas perkebunan di wilayah masing-masing.

Berdasarkan teori kabupaten sebagai unit terkecil memiliki kriteria daerah kunci, antara lain: (a) Daerah ini memiliki sopir ekonomi regional kegiatan ekonomi, (b) Daerah harus memiliki keuntungan dari sektor ekonomi yang dapat mendorong sektor lain kegiatan ekonomi di wilayah itu sendiri dan efek, dan (c) Daerah andalan tidak bisa berdiri sendiri tetapi harus memiliki relevansi dengan depan dan belakang dengan beberapa daerah / wilayah mendukung.

Potensi sentra produksi unggul kecamatan didukung oleh sumber daya alam yang masih memungkinkan untuk dikembangkan membutuhkan sentuhan teknologi dan modal yang memadai. Secara teoritis, perlu untuk memiliki perencanaan yang baik, masalah utama dari teknologi dan modal. Model yang sesuai harus memiliki rencana sesuai dengan konsep pembangunan suatu daerah. Model perencanaan dasar ekonomi sebagai salah satu pendekatan yang digunakan dalam identifikasi sektor potensial yang dapat menjadi pendorong pertumbuhan dan perkembangan daerah adalah teori basis ekonomi. Menurut teori ini, pertumbuhan dan perkembangan suatu daerah tergantung pada permintaan dari luar daerah ke daerah produksi. Ekonomi suatu daerah dibagi menjadi sektor atau sektor basis dasar dan basis ekspor.

Model pembangunan tidak dapat diterapkan dan dilaksanakan dalam hal perbedaan antara potensi daerah dengan kemampuan sumber daya, baik modal dan penguasaan datang ke teknologi. Hasil menunjukkan bahwa sub-wilayah sebagai unit terkecil di daerah ini memiliki potensi yang bervariasi sesuai dengan agroklimat, komunitas pertanian agro-ekologi dan kemampuan. Dalam mengembangkan kedua spesialisasi komoditas dan diversifikasi juga sangat tergantung pada infrastruktur dan jumlah lahan yang tersedia yang memenuhi persyaratan teknis.

Hasil di atas adalah untuk sebagian besar kabupaten (8 dari 12 kabupaten) masih menggunakan strategi diversifikasi pembangunan. Komoditas diversifikasi per kabupaten akan mengurangi risiko. Risiko terbesar bagi pembangunan adalah perubahan arah dari permintaan komoditas, harga, dan risiko budidaya. Untuk mengatasi pengembangan komoditas ini di semua kabupaten di Aceh menggunakan strategi diversifikasi, yang ditunjukkan dengan nilai $\beta<1$, setiap kabupaten mengembangkan lebih dari satu komoditas dan untuk setiap tukang kebun untuk menanam lebih dari satu perkebunan tanaman. Ada kecenderungan bahwa komoditas menjadi perkebunan atas di kabupaten ini tidak secara komoditas, seperti pertumbuhan areal dan produksi relatif lambat. Berbeda dengan uraian di atas, komoditas lain yang tidak sebagai komoditas andalan menjadi komoditas dasar di kabupaten. 
Hasil ini juga sesuai dengan yang diperoleh oleh Dillon (2006) bahwa komoditas perkebunan yang memiliki untuk mengembangkan potensi unggul yang relatif lebih cepat di distrik yang bersangkutan, tidak selalu komoditas utama. Sebagai contoh untuk komoditas lada yang sebagian besar di 20 kecamatan, tidak menjadi komoditas karena perkembangannya relatif lebih lambat dan cenderung terganggu di kecamatan atau kabupaten lain dari kabupaten secara keseluruhan. Hal ini berlaku juga pada komoditas dari cocoas di dua kabupaten di pantai timur Aceh, meskipun pertumbuhan relatif lebih cepat adalah di kecamatan atau kabupaten lain dari kabupaten secara keseluruhan, tapi komoditas tidak secara komoditas di dua kabupaten yang sehingga tidak termasuk dalam komoditas andalan kecamatan.

Perkembangan komoditas petani di daerah ini tergantung pada keberanian petani beresiko. Komoditi spesialisasi mendorong produktivitas yang tinggi, tetapi mungkin pendapatan rendah. Penurunan permintaan dan harga sering menyebabkan kelesuan dalam produksi, seperti yang dialami di Lhoknga Kabupaten, petani Kakao dan pulau Aceh. Alih-alih kenaikan harga dan permintaan meningkat memotivasi areal dan produksi seperti yang terjadi di komoditas kakao di daerah ini. Dalam jangka waktu tiga tahun (2005-2008) ada peningkatan di areal antara 14 sampai 21 persen dalam lima sentra produksi cocoas. Sebaliknya ada pengurangan panen Kakao antara 5 hingga 8 persen untuk pusat produksi kakao di Aceh. Kebanyakan petani mencari lebih dari satu tanaman di tanah. Dengan demikian kontribusi pendapatan masing-masing komoditas relatif kecil. Selama pengembangan komoditas perkebunan di daerah ini belum mengacu pada rencana induk perkebunan Aceh. Akibatnya, pola diversifikasi yang mengandalkan petani kreativitas yang lebih dominan.

\section{Kesimpulan}

Perkembangan komoditas petani di Aceh belum konsisten dengan potensi masingmasing sentra produksi sub-region. Beberapa faktor yang menyebabkan inkonsistensi ini, antara lain: (a) pengembangan petani tidak sesuai dengan rencana induk perkebunan Aceh yang telah diterbitkan sejak tahun 2007, (b) sebagian besar perkebunan rakyat dalam organisasi Aceh masih mengandalkan pada pemahaman komoditas masih rendah, (c) anggaran belum dialokasikan untuk pembangunan perkebunan yang optimal; (D) peran lembaga tinggi aktif pendidikan rendah untuk menguji kesesuaian potensi daerah dengan daerah komoditas.

\section{Daftar Pustaka}

Agussabti dan Romano, 2011. Comprehensif Study on Nutmeg Farming as Prime Commodity Relay for Aceh Peace and Gender on Development, FORUM PALA Aceh dan UNDP.

Dillon, 2006. Agriculture Piloce. Jurnal Forum Penelitian Agro Ekonomi. Vol.24. Page. 9093

Galindo,Isabel Morales, Regional Development Through Knowledge Creation In Organic Agriculture,Journal Of Knowledge Management,Vol 11 No 5,Emerald Group Publishing United,2007

Glasson, John. 1990. Regional Planing. Translat by Paul Sihotang. UI Press. Jakarta 
Hendri, David, 2005, Sintesys character on Agropolitant Zone Planning, Gadjah Mada University Press, DIY.

Hendayana Rahmah, Location Quotient ( LQ ) Aplication Methode on National Prime Commodity, Jurnal of Agriculture Informatic Desember 2003 Edition Bogor. Page. 112-115

Hoover, Edgar M. and Frank Giarratani. 2002. An Introduction to Regional Economics : How Regions Development. Needleman.

Warpani,2008. Location Quotient ( LQ ) Aplication Methode on Comprehensive reliability Criteria, Jurnal of Agriculture Informatic Desember 2008 Edition Bogor. Page. 64-75 